\title{
PENATAAN JALUR PEJALAN KAKI BERDASARKAN AKTIVITAS PENGGUNA KORIDOR PADA KORIDOR SEI RAMPAH
}

\author{
Dwira Nirfalini Aulia ${ }^{1}$, Fabiani Novitasari ${ }^{2}$ \\ ${ }^{1,2}$ Program Studi Magister Teknik Arsitektur Fakultas Teknik Universitas Sumatera Utara \\ Jl. Perpustakaan St. J07 Building, Medan, 20155, Indonesia \\ Email:1'dwira_aulia@yahoo.com, ${ }^{2}$ fabianinovitasarii@gmail.com
}

\begin{abstract}
ABSTRAK
Koridor Sei Rampah yang terletak di jalan arteri lintas Sumatera merupakan penunjang kehidupan sosial dan ekonomi yang ditandai dengan aktivitas yang cukup tinggi. Bangunan di sepanjang koridor terdiri dari ruko lama dan ruko baru yang mempunyai kondisi perkerasan yang tidak baik serta penggunaan jalur pejalan kaki yang tidak efisien. Ruko-ruko baru mempunyai garis sampadan bangunan yang bisa dimanfaatkan sebagai lahan parkir sekaligus jalur pejalan kaki dan sudah menggunakan material yang baik. Namun jalur pejalan kaki pada ruko baru kurang dimanfaatkan dengan baik karena banyak pedagang kaki lima yang menggunakannya sebagai area jualan. Identifikasi terhadap koridor Sei Rampah bertujuan untuk mewujudkan jaringan pejalan kaki yang aman, nyaman, serta dilengkapi dengan perabot jalan seperti lampu, tempat sampah, tempat duduk, halte, papan reklame dan lain lain sehingga mampu mendorong masyarakat untuk lebih senang berjalan kaki serta bisa dilalui oleh semua orang termasuk para penyandang cacat. Metode yang digunakan dalam penelitian adalah metode kualitatif yang bersifat deskriptif dan cenderung menggunakan analisis yang lebih menonjolkan proses dan makna perspektif subjek. Dari hasil penelitian maka diperoleh rumusan hasil pengamatan perilaku pengguna koridor yang kemudian dapat ditentukan kebutuhan fasilitas pejalan kaki dan dimensi perabot jalan yang akan dikembangkan sesuai dengan peraturan dan ketentuan yang berlaku sebagaimana diatur oleh pemerintah daerah Kota Sei Rampah maupun dari pemerintah Kabupaten Serdang Bedagai. Dengan menerapkan pedoman penataan jalur pejalan kaki berdasarkan aktivitas pengguna koridor diharapkan dapat menciptakan jalur pejalan kaki yang baik pada koridor Sei Rampah.
\end{abstract}

Kata Kunci: koridor, penataan koridor, jalur pejalan kaki.

\section{PENDAHULUAN}

Kota Sei Rampah yang terletak di jalan arteri lintas Sumatera merupakan penunjang kehidupan sosial dan ekonomi yang ditandai dengan aktivitas yang cukup tinggi. Letak pusat kota Sei Rampah disepanjang jalur jalan arteri membuat banyak aspek yang harus dikaji dalam membuat perencanaannya.

Jalan sebagai salah satu elemen dasar pembentuk kawasan merupakan salah satu ruang publik perkotaan yang paling mudah diamati untuk memahami karakteristik sebuah kawasan, oleh karena itu jalan merupakan pembentuk citra kota yang paling utama (Lynch, 1960). Jalan lebih dari suatu perlengkapan sebuah kota, jalan lebih dari sekedar garis air, garis selokan, garis tiang listrik/kabel listrik, lebih dari ruang linear yang memindahkan orang dan barang dari sini ke sana, sehingga ruang jalan kota sebagai koridor kota dapat memberikan berbagai macam makna (Jacobs, 1993) (Gambar 2).

Aktivitas komersil di koridor Sei Rampah mengundang para pelaku aktivitas di ruang publik lain memanfaatkan hilir mudik pejalan kaki. Aktor pengguna ruang publik tersebut menempati sebagian badan jalan sebagai tempat parkir kendaraan dan juga area berjualan pedagang kaki lima.

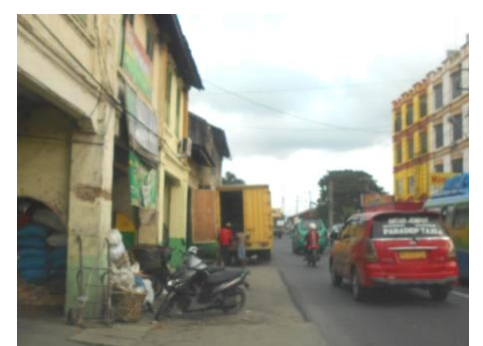

Gambar 2. Suasana Aktivitas pada Koridor Sei Rampah

Edisi cetak 
Pelaku aktivitas ruang publik pada koridor Sei Rampah lebih banyak berjalan kaki untuk berinteraksi pada koridor ini. Berjalan merupakan alat untuk pergerakan internal kota dan merupakan alat untuk memenuhi kebutuhan interaksi tatap muka yang ada di dalam aktivitas komersial dan budaya di lingkungan kehidupan kota. Kedudukan berjalan adalah sebagai alat penghubung antara moda-moda angkutan yang tidak mungkin dikerjakan oleh moda angkutan lain (Rochadi, 1991).

Koridor Sei Rampah dipenuhi oleh bangunan ruko lama yang mengadaptasikan arsitektur pecinan dan beberapa bangunan ruko yang telah dibangun menjadi lebih modern. Menurut hasil penelitian, pada sirkulasi pejalan kaki bagian bangunan ruko lama pecinan tidak memiliki sirkulasi pejalan kaki yang baik. Pedestrian yang ada di halaman depan bangunan banyak yang sudah pecah dan berlubang sehingga membuat pejalan kaki tidak nyaman untuk melintasinya (Gambar 3).

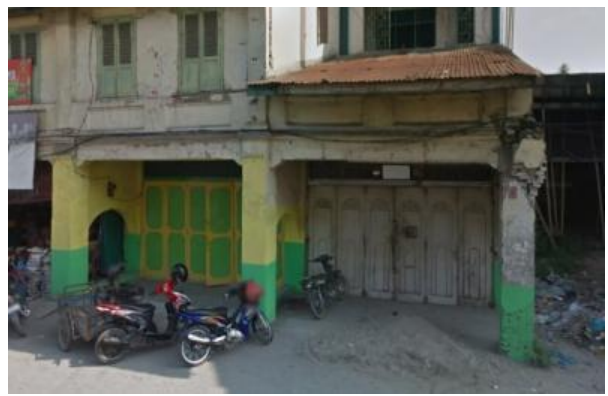

Gambar 3. Jalur Pejalan Kaki pada Ruko Lama Koridor Sei Rampah

Selain itu, jalur pejalan kaki juga dimanfaatkan toko sebagai etalase pajangan barang dagangan seperti toko baju sebagai lahan jualan mereka (Gambar 4).

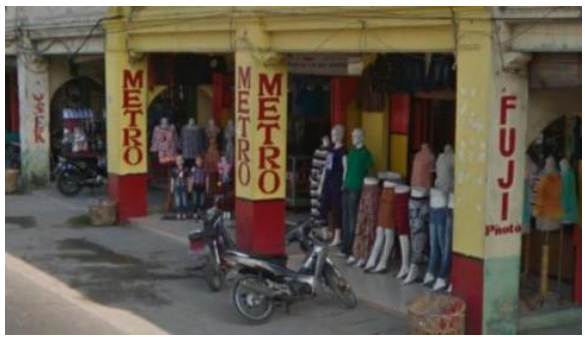

Gambar 4. Jalur Pejalan Kaki yang Dimanfaatkan sebagai Etalase Pajangan

Pada bagian ruko yang baru, jalur pejalan kaki sudah bisa dimanfaatkan karena kondisi pedestriannya yang sudah baik. Namun jalur pejalan kaki pada ruko baru juga kurang efisien dikarenakan banyak pedagang kaki lima berjualan pada lahan yang seharusnya digunakan sebagai jalur pejalan kaki ini (Gambar 5).

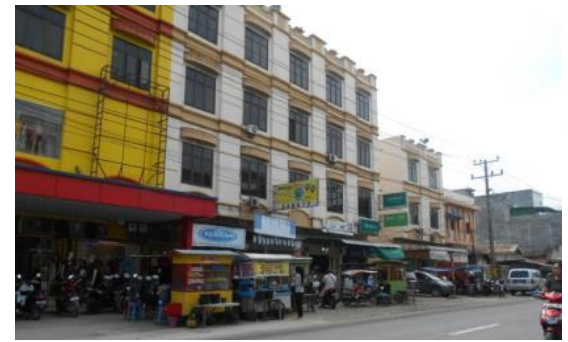

Gambar 5. Jalur Pejalan Kaki pada Ruko Baru Koridor Sei Rampah

Peraturan Menteri Pekerjaan Umum nomor 03/PRT/M/2014 [4], kriteria dan spesifikasi ruang bebas jalur pejalan kaki dimaksud harus diperhatikan dalam penempatan utilitas/perlengkapan lainnya. Ilustrasi untuk ruang bebas jalur pejalan kaki (Gambar 6).

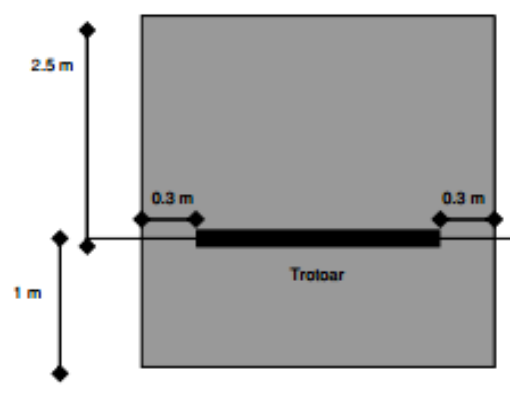

Gambar 6. Ilustrasi Ruang Bebas Jalur Pejalan Kaki

Sirkulasi pejalan kaki direncanakan untuk bisa dilalui oleh semua anggota masyarakat termasuk para penyandang cacat. Selain itu dilengkapi dengan perabot jalan seperti lampu, tempat sampah tempat duduk, halte, papan reklame dan lain lain. Pada jalur pedestrian, trotoar dilengkapi dengan jalur untuk penyandang cacat dengan material guiding block yang bertekstur kasar (Gambar 7).

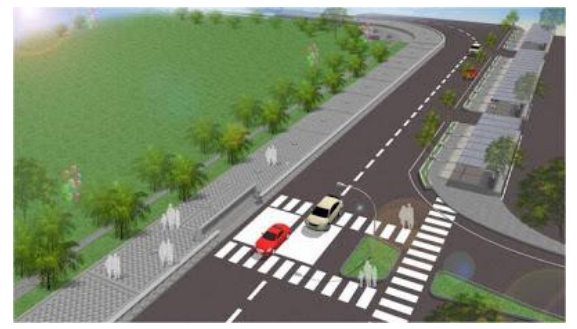

Gambar 7. Konsep Sirkulasi Pejalan Kaki di Kota 
Jaringan pejalan kaki memiliki perbedaan ketinggian baik dengan jalur kendaraan bermotor ataupun dengan jalur perabot jalan. Perbedaan tinggi maksimal antara jalur pejalan kaki dan jalur kendaraan bermotor adalah 0,2 meter, sementara perbedaan ketinggian dengan jalur hijau 0,15 meter (Gambar 8).

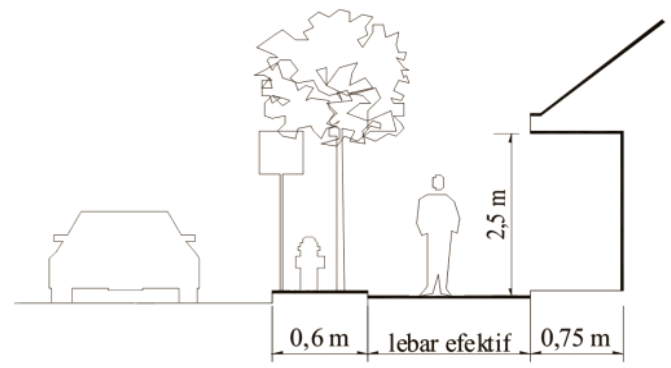

Gambar 8. Jalur Pejalan Kaki/Pedestrrian

Seperti pada koridor Jalan Michigan, Amerika Serikat, pejalan kaki memerlukan tempat untuk berjalan aman dan nyaman, rencana ini lebih ditempatkan pada Jalan Lyon dibatasi ruang dan lalu lintas yang padat. Pendekatan ini menunjukkan bahwa lingkungan untuk pejalan kaki, pengendara sepeda, dan transit pengendara sering diabaikan, membuat jalan kurang aman dan tidak nyaman bagi pejalan kaki. Pemerintah memberikan perhatian khusus kepada perbaikan untuk pejalan kaki. Berbagai fasilitas disertakan di standar untuk rencana review untuk pengendara sepeda, pejalan kaki, dan tempat penyimpanan sepeda.

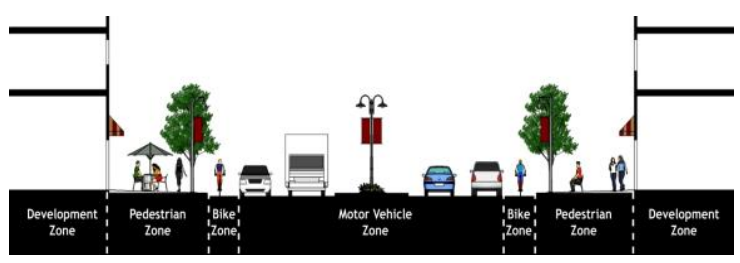

Gambar 9. Penampang Melintang Koridor Jalan Michigan

Beberapa blok sepanjang koridor jalan Michigan cukup nyaman dimana pejalan kaki dilindungi dari lalu lintas dengan taman pada lansekap.

\section{METODE PENELITIAN}

Penelitian yang dilakukan pada koridor Sei Rampah ini menggunakan metode kualitatif yang bersifat deskriptif dan cenderung menggunakan analisis yang lebih menonjolkan proses dan makna perspektif subjek. Peristiwaperistiwa yang terjadi dalam situasi sosial pada jalur pejalan kaki di koridor Sei Rampah merupakan kajian utama penelitian kualitatif. Aktivitas yang terjadi pada koridor Sei Rampah dijadikan kajian dalam membuat perencanaan penataan koridor. Proses analisa pada lokasi penelitian disimpulkan dengan menghubungkan dengan kebijakan pemerintah dan studi banding koridor jalan Michigan, Amerika Serikat dan menerapkannya pada ilustrasi perencanaan. Hasil penelitian ini akan menjadi masukan bagi pemerintah Ibukota Kabupaten Serdang Bedagai yaitu Kota Sei Rampah sebagai pedoman penataan jalur pejalan kaki.

\section{HASIL DAN PEMBAHASAN}

Dalam perencanaan penataan jalur pejalan kaki yang perlu diperhatikan adalah kebebasan berjalan untuk mendahului serta kebebasan waktu berpapasan dengan pejalan kaki lainnya tanpa bersinggungan, dan kemampuan untuk memotong pejalan kaki lainnya. Potensi yang dapat diidentifikasi dari kasus koridor Sei Rampah ditinjau dari aspek sirkulasi pejalan kaki adalah menciptakan jalur pejalan kaki yang baik pada koridor Sei Rampah dengan penataan jalur pejalan kaki berdasarkan aktivitas yang terjadi pada koridor tersebut.

Dalam buku standar Tata Cara Perencanaan Fasilitas Pejalan Kaki Di Kawasan Perkotaan [6], yang dihasilkan oleh Direktorat Bina Teknik, untuk menjadi Rancangan SNI, fasilitas pejalan kaki harus direncanakan berdasarkan ketentuan-ketentuan sebagai berikut:

1. Pejalan kaki harus mencapai tujuan dengan jarak sedekat mungkin, aman dari lalu lintas yang lain dan lancar.

2. Terjadinya kontinuitas fasilitas pejalan kaki, yang menghubungkan daerah yang satu dengan yang lain.

3. Jalur pejalan kaki yang memotong jalur lalu lintas berupa penyeberangan (Zebra Cross), marka jalan dengan lampu pengatur lalu lintas (Pelican Cross), jembatan penyeberangan dan terowongan.

4. Fasilitas pejalan kaki harus dibuat pada ruas-ruas jalan di perkotaan atau pada tempat-tempat dimana volume pejalan kaki memenuhi syarat atau ketentuan-ketentuan untuk pembuatan fasilitas tersebut. 
5. Jalur pejalan kaki sebaiknya ditempatkan sedemikian rupa dari jalur lalu lintas yang lainnya, sehingga keamanan pejalan kaki lebih terjamin.

6. Dilengkapi dengan rambu atau pelengkap jalan lainnya, sehingga pejalan kaki leluasa untuk berjalan, terutama bagi pejalan kaki yang tuna daksa.

7. Perencanaan jalur pejalan kaki dapat sejajar, tidak sejajar atau memotong jalur lalu lintas yang ada.

8. Jalur pejalan kaki harus dibuat sedemikian rupa sehingga apabila hujan permukaannya tidak licin, tidak terjadi genangan air serta disarankan untuk dilengkapi dengan pohonpohon peneduh.

9. Untuk menjaga keamanan dan keleluasaan pejalan kaki, harus dipasang kerb jalan sehingga fasilitas pejalan kaki lebih tinggi dari permukan jalan.

Analisa kasus proyek koridor Sei Rampah ditinjau dari aspek sirkulasi pejalan kaki dapat dibagi dalam 3 segmen (Gambar 10).

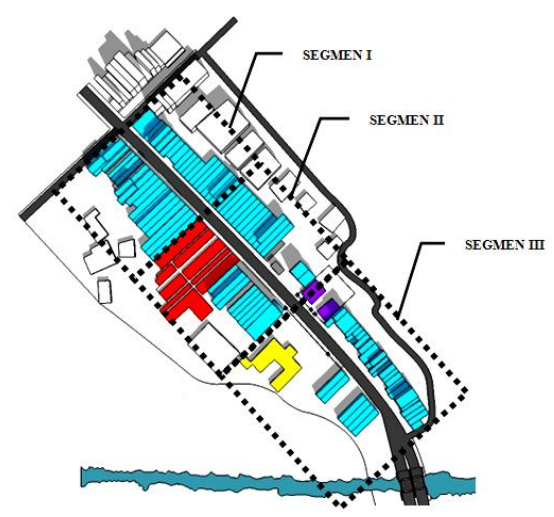

Gambar 10. Pembagian Batas Segmen Sirkulasi Pejalan Kaki Koridor Sei Rampah

\section{Segmen I}

Sirkulasi pejalan kaki pada segmen I tidak mempunyai kondisi yang baik. Perkerasan pada jalur pedestrian banyak yang rusak, sehingga membuat pejalan kaki tidak nyaman untuk melintasinya.

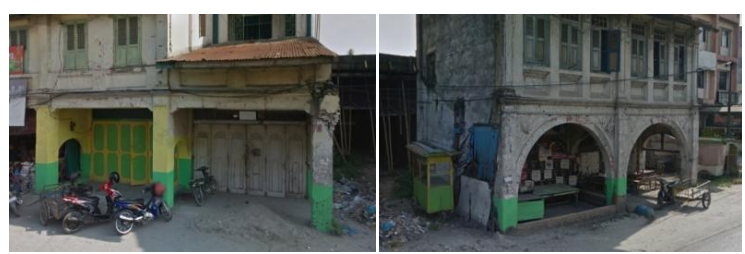

Gambar 11. Kondisi Eksisting Jalur Pejalan Kaki pada Segmen I Koridor Sei Rampah
Selain itu, jalur pedestrian ada yang dimanfaatkan toko sebagai etalase pajangan barang dagangan seperti toko baju dibawah ini yang memanfaatkan jalur pejalan kaki sebagai lahan jualan mereka.

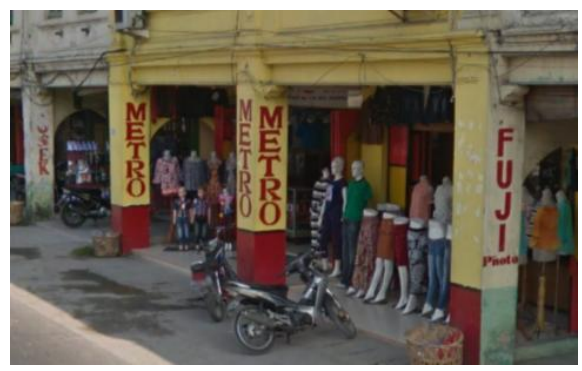

Gambar 12. Kondisi Eksisting Jalur Pejalan Kaki pada Segmen I Koridor Sei Rampah

Untuk penataan jalur pejalan kaki berdasarkan aktivitas pengguna koridor pada segmen I sesuai dengan studi banding dan juga peraturan yang ada maka perencanaan yang akan diterapkan pada segmen I adalah sebagai berikut:

1. Memberi rambu lalu lintas serta zebra cross untuk para penyebrang jalan di area persimpangan jalan Stasiun dan jalan Sinangkong yang juga merupakan titik keramaian pada segmen I (Gambar 13).

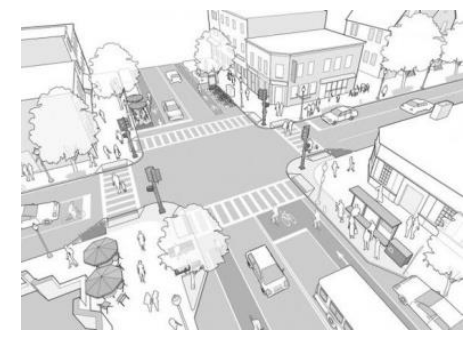

Gambar 13. Ilustrasi Penyebrangan pada Persimpangan Jalan Stasiun dan Jalan Sinangkong

2. Segmen I yang dipenuhi dengan bangunan ruko lama pecinan, jalur pedestriannya berada dibawah lorong bangunannya ditata ulang dengan menggunakan material yang baik yang bisa dilalui oleh orang umum termasuk disabilitas dan dipasang kerb jalan sehingga fasilitas pejalan kaki lebih tinggi dari permukaan jalan (Gambar 14). 


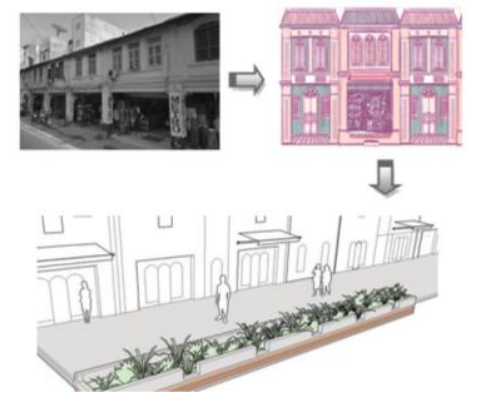

Gambar 14. Ilustrasi Rencana Pedestrian Segmen I

\section{Segmen II}

Kondisi jalur pejalan kaki pada segmen II sudah tertata lebih baik, karena pada segmen II ini terdiri dari bangunan ruko lama pecinan namun ada juga ruko-ruko baru yang mempunyai GSB yang bisa dimanfaatkan sebagai lahan parkir sekaligus jalur pejalan kaki. Sirkulasi pejalan kaki pada ruko-ruko yang baru juga sudah menggunakan material yang baik dengan diberi perkerasan (Gambar 15).
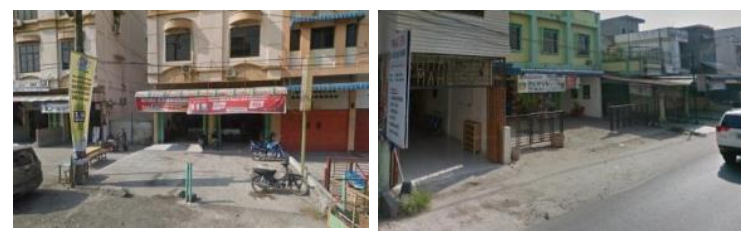

Gambar 15. Kondisi Eksisting Jalur Pejalan Kaki pada Segmen II Koridor Sei Rampah

Namun jalur pejalan kaki pada ruko baru ini juga kurang efisien dikarenakan banyak pedagang kaki lima berjualan pada lahan yang seharusnya digunakan sebagai jalur pejalan kaki ini (Gambar 16).

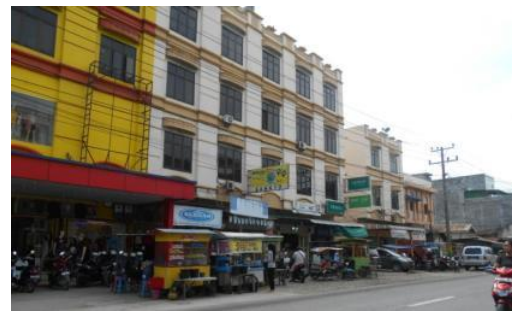

Gambar 16. Kondisi Eksisting Jalur Pejalan Kaki pada Segmen II Koridor Sei Rampah

Untuk penataan jalur pejalan kaki berdasarkan aktivitas pengguna koridor pada segmen II sebagai berikut (Gambar 17):

1. Kondisi pedestrian yang sudah cukup baik dari segi material dan juga ukurannya yang lebar, perlu ditata kembali dengan menambahkan rambu atau pelengkap jalan lainnya sehingga memberikan kenyamanan untuk pejalan kaki termasuk disabilitas.

2. Masalah yang timbul dari PKL yang berjualan diarea pedestrian dapat diberi ruang khusus untuk dagangan mereka serta sekaligus memberi area duduk pada kawasan pedestrian.

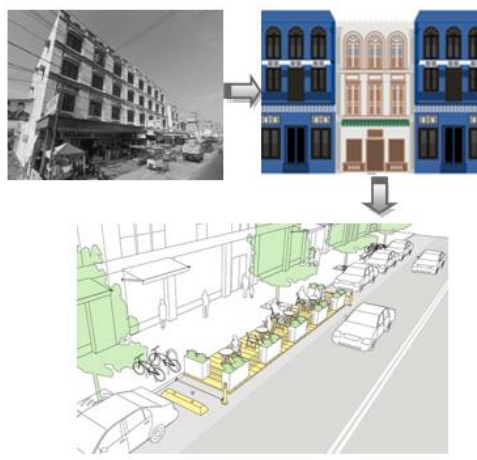

Gambar 17. Ilustrasi Rencana Pedestrian Segmen II

\section{Segmen III}

Bagian segmen III terdiri dari bangunan baru dan ada juga beberapa ruko yang masih merupakan bangunan ruko lama pecinan, maka isu yang terjadi pada segmen ini yaitu jalur pejalan kaki yang sudah tertata cukup baik pada bangunan baru, namun pada bangunan ruko lama pecinan mempunyai kondisi yang rusak (Gambar 18).

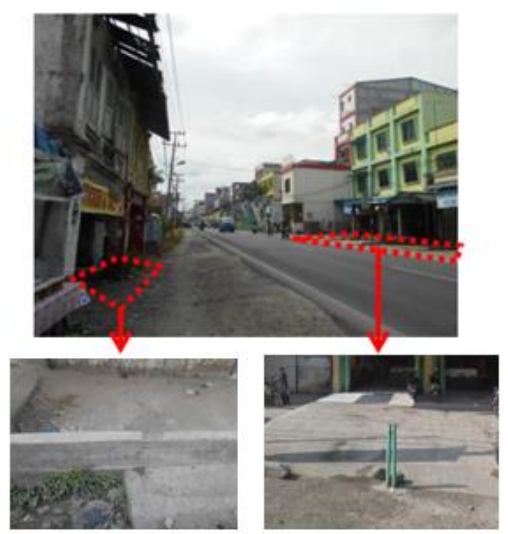

Gambar 18. Kondisi Eksisting Jalur Pejalan Kaki pada Segmen III Koridor Sei Rampah

Menurut perencanaan koridor Sei Rampah dalam aspek penggunaan tanah, segmen III ini direncanakan sebagai segmen dengan keseragaman fasad ruko baru, maka dari itu pedestrian yang ada pada segmen ini akan dibuat sesuai dengan aturan GSB yang berlaku dan ditata dengan fasilitas pejalan kaki sesuai standar nasional (Gambar 19). 


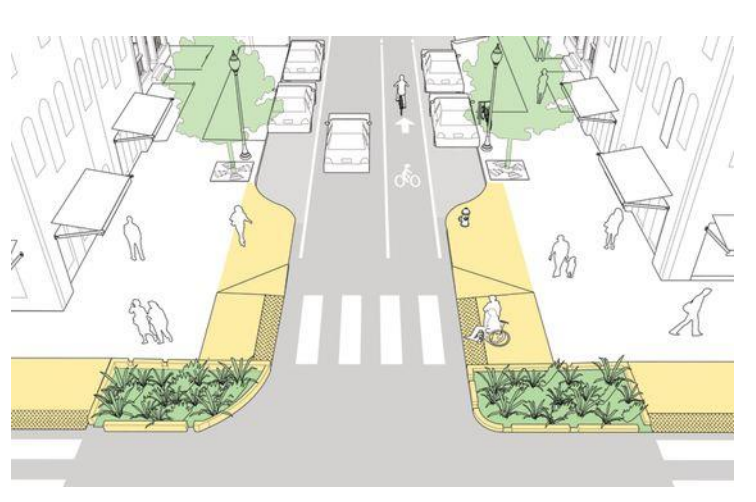

Gambar 19. Ilustrasi Rencana Pedestrian Segmen III

Jalur pejalan kaki pada segmen III mempunyai lebar yang cukup luas, dan dilengkapin dengan rambu dan perabot seperti lampu taman, tempat duduk, tanaman, serta ada jalur ram untuk para disabilitas.

\section{KESIMPULAN}

Koridor Sei Rampah yang merupakan pusat perdagangan, mempunyai bangunan multi fungsi yang digunakan sebagai tempat hunian pada lantai atas dan lantai dasar sebagai toko, maka dari itu dibutuhkan kenyamanan jalur pejalan kaki untuk berbagai orang termasuk disabilitas yang ditata sesuai dengan teori studi banding yang telah dianalisa dan peraturan yang berlaku sebagai standar perencanaan.

Jalur pejalan kaki pada koridor yang berada pada bagian bangunan lama ruko pecinan ditata dengan material yang baik walaupun lebarnya tidak dibuat cukup besar karena mengikuti foyer yang terbentuk dari bangunan pecinan. Namun jalur pejalan kaki pada bagian ruko yang baru memiliki lebar pedestrian yang cukup besar dan nyaman serta ditata dengan memberi ruang tersendiri untuk pedagang kaki lima dan memberi rambu lengkap serta perabot pedestrian seperti lampu, bangku taman, tanaman hijau, dan diberi jalur ram khusus untuk para disabilitas.

\section{Daftar Pustaka}

City Commission Resolution of Adoption (2015) Michigan Street Corridor Plan.

Lynch (1960) The Image of The City. The MIT Press, Cambridge, Massachusetts.
Jacobs, Allan B. (1993) Great Streets. Cambridge. MIT Press.

Peraturan Menteri Pekerjaan Umum Nomor: 03/Prt/M/2014/2011 tentang Pedoman

Perencanaan, Penyediaan, Dan Pemanfaatan Prasarana Dan Sarana Jaringan Pejalan Kaki di Kawasan Perkotaan. Jakarta.

Tri Rochadi, Mohammad, et al. (1991) Teori Perancangan Urban. Bandung: Program Pasca Sarjana Institut Teknologi Bandung.

Tata Cara Perencanaan Fasilitas Pejalan Kaki di Kawasan Perkotaan (1995) Direktorat Jenderal Bina Marga, Departemen Pekerjaan Umum, Jakarta. 